\section{ASPECTS OF PLANT NUTRITION}

Nutrition of the Legumes

Proceedings of the University of Nottingham Fifth Easter School in Agricultural Science, 1958. Edited by Prof. E. G. Hallsworth. Pp. $x+360$. (London : Butterworths Scientific Publications; New York: Academic Press, Inc., 1958.) 55s.

Utilization of Nitrogen and Its Compounds by Plants

Symposia of the Society for Experimental Biology, No. 13. Edited by H. K. Porter. Pp. vii +385 . (Cambridge: At the University Press, 1959. Published for the Company of Biologists on behalf of the Society for Experimental Biology.) 50s. net.

$\mathrm{T}$

HIS is an age of conferences, and both the Society for Experimental Biology and the Agricultural Department of the University of Nottingham can claim a high degree of success for those they organize in their respective fields of interest. In 1958 the topies of the Symposium of the Society for Experimental Biology and of the University of Nottingham Fifth Easter School in Agricultural Science overlapped considerably, for in a discussion on the nutrition of legumes, the subject of the latter, the uptake and utilization of nitrogen, the subject of the former, must obviously demand a leading, though by no means exclusive, part.

In the Nottingham Easter School the various aspects of legume nutrition were well covered by the twenty-four papers provided by the various contributors. These papers were classified in five groups : the plant component, the rhizobial component, the symbiotic system, biochemical aspects and field aspects. The papers in the first group, apart from one on the classification of the Leguminosae by Prof. Tutin, were concerned with minoral nutrition, particular attention being given to micronutrients and aluminium. Among the second group were contributions on the classification of Rhizobia, the physiology of nodule formation, the survival of the root nodule bacteria outside the host plant and a general consideration of the symbiotic fixation of nitrogen in the Leguminosae. The third group of papers was largely concerned with factors affecting the uptake of nitrogen by legumes and factors affecting nodulation, but included in this group was a paper by Dr. G. Bond on symbiotic fixation of nitrogen by eight genera of angiosperms outside the Leguminosae. The biochemical aspects considered in the fourth group were nitrogen fixation, the transport of amino-acids, and the effect of iron deficiency on amino-acid metabolism in the yellow lupin. The papers concerned with field aspects dealt with a rather miscellaneous assortment of topics ranging from the tolerance of lucerne to excess manganese and copper deficiency in the field to the growth of a clover sward.

In the Symposium of the Society for Experimental Biology the emphasis was mainly biochemical, as was to be expected when the theme was the utilization of nitrogen. The course of nitrate reduction and the enzymes concerned in it, various aspects of the metabolism of amino-acids, including their assimilation and utilization, the biosynthesis of amide and peptide bonds, the formation of alkaloids, and the relation of nucleic acids to plant growth and development, were among the subjects of the twenty papers contributed to the Svmposium.
The papers presented at both these conferences varied considerably in respect to the amount of original unpublished information contained in them. It would perhaps be best to regard them as essays giving an up-to-date account of the respective subjects with which they dealt, written by experts actively working in their various fields. As such they provide a wealth of information on the nutrition of the Leguminosae and the utilization of nitrogen by plants in general.

The esteem in which these conferences are held and the value placed on them by the participants is indicated by the number of overseas visitors taking part. In the Nottingham School 40 per cent, and in the Society for Experimental Biology Symposium 50 per cent of the papers were given by workers abroad who came from Australia and New Zealand, Canada and the United States, Belgium, Holland, Denmark, Finland, Germany and the U.S.S.R. Walter Stiles

\section{PARASITIC HELMINTHS}

Medical Helminthology

By Dr. J. M. Watson. Pp. $x i+487$, (London: Baillière, Tindall and Cox, Ltd., 1960.) 84s.

70 summarize, in a convenient form, all the work that has been done in the past half-century on the human diseases caused by helminths is not an easy task; and when an author includes, as Watson does, references to diseases caused in other animals by these parasitic worms, the task is greater still. Watson has, however, had long experience of his subject. $\mathrm{H}_{\theta}$ was senior helminthologist to the Wellcome Laboratories in London, served as a member of the World Health Organizations' Expert Committee on Parasitic Diseases and has been professor of zoology and of parasitology and bacteriology in the University of Baghdad. The book he now gives us is based on lectures he gave at the American University of Beirut, and the manuscript of it has been checked by English, Canadian and American experts whose names are household words in tho field of parasitology.

Part I of the book is a general introduction to the subject, which reviews the eomparatively brief history of helminthology and discusses the zoological position of parasitic helminths, their relations with their hosts and the geographical distribution of the important species which infect man. In the bulk of the book (Part 2) the author gives an account of the helminths themselves, arranging these, not, as most text-books on this subject do, according to their zoological position, but according to the tissues which they attack. This is, the author thinks. clinically more convenient and no doubt many will agree. Others will prefer the zoological plan, which at least has the merit of bringing together the types of lesions caused by nematodes, cestodes and trema. todes, respectively. The third part of the book discusses the diagnosis, treatment and prevention of helminth infections, and appendixes provide a bibliography, all too short, some may think, of key references to the vast literature, a valuable chapter on the rules of zoological nomenclature and another, which research workers will find useful, on the helminth infections of common laboratory animals. In his final chapter the author gives, among other facts, notes on the rapid recent advances in our knowledge of vectors and anthelmintics. 